\title{
Further Studies on Episodic Occurrence of Congenital Dysgenetic Hypothyroidism in Osaka, Japan
}

\author{
KIYOSHI MIYAI, KAZUTAKA INAOKA* AND TOMIKO MIYAGI** \\ COMMITTEE FOR NEWBORN AND INFANT SCREENING IN OSAKA (CONISO)*** \\ Osaka University (Professor Emeritus), 8-7-36, Mino, Mino-shi, Osaka 562-0001, Japan \\ *Department of Clinical Laboratory Medicine and Anatomic Pathology, Osaka Medical Center and Research Institute, Osaka, Japan \\ **Clinical Laboratory, Osaka City Environment and Public Health Association, Osaka, Japan
}

\begin{abstract}
A total of 1,228,551 newborn babies, who were almost all of babies born in Osaka for 14 years (168 months), were screened for congenital primary hypothyroidism by an identical mass-screening program using the thyrotropin method, and 429 patients with hypothyroidism due to thyroid dysgenesis (dysgenetic hypothyroidism) were found. The occurrence of the patients in every month was not random but episodic and the incidence was higher in the late autumn (from October to December). These observations support a hypothesis that some environmental factors may cause this disorder overtime and the possibility of relation with intrauterine viral infection was discussed.
\end{abstract}

Key words: Neonatal screening, Congenital hypothyroidism, Episodic occurrence, Environmental factors, Intrauterine viral infection

(Endocrine Journal 52: 599-603, 2005)

CONGENITAL hypothyroidism $(\mathrm{CH})$ is a well known disease causing mental and growth retardation and various types of the disease have been recognized [1]. The etiology of the developmental defect of the thyroid termed thyroid dysgenesis including thyroid aplasia, hypoplasia and ectopic thyroid has not yet been clarified, even if the congenital hypothyroidism due to thyroid dysgenesis (dysgenetic $\mathrm{CH}$ ) is the most common cause of $\mathrm{CH}$ [1]. In 1954 Childs and Gardner [2] reported that occurrence of $\mathrm{CH}$ had no significant seasonal variation. On the contrary, Miyai et al. [3] demonstrated the seasonal occurrence of $\mathrm{CH}$ in the Osaka area in Japan and proposed a hypothesis that an unknown environmental factor may cause the disease. Subsequent studies revealed that the seasonal occur-

Received: February 28, 2005

Accepted: July 11, 2005

Correspondence to: Kiyoshi MIYAI, M.D., Ph.D., 8-7-36, Mino, Mino-shi, Osaka 562-0001, Japan

***Members: Shintaro Okada (chairman), Kiyoshi Miyai (past chairman), Gen Issiki, Jun-ichi Furuyama, Naoyuki Ito, Tsuneo Tsuruhara, Hideo Nishino, Yutaka Hase, Masanori Fujimura, Masahiro Nakayama, Eizo Kanoh, Akihiro Matsushita rence of the disease was observed in some areas (Japan, Australia, Quebec and Toronto) but the seasons were not identical and such seasonality could not be found in other areas (Pennsylvania, Norway, France and Switzerland) [4]. Even if an environmental factor may relate to the occurrence of $\mathrm{CH}$, they would be masked when a small number of patients from heterogeneous sources (from hospitals or general population by different mass-screening programs) were analyzed in wide areas for short periods.

Therefore this study was designed to analyze the occurrence of dysgenetic $\mathrm{CH}$ with a large number of patients found in the general population by an identical mass-screening program in a restricted area for long period.

\section{Subjects and Methods}

The study was performed in Osaka prefecture and Osaka city (total area: $1,893 \mathrm{~km}^{2}$, averaged general population: $8,800,000)$ for 14 years (168 months) from January 1989 to December 2002. 


\section{Subjects}

The original data of $\mathrm{CH}$ were obtained from the Report of the CONISO with its permission. The patients with primary $\mathrm{CH}$ were found in the general population by an identical neonatal mass-screening program. Thyrotropin in dried blood samples on filter paper taken from the neonatal babies was measured by the enzyme immunoassay using a commercial kit (Eiken Co., Tokyo) [5-7]. The final diagnosis of $\mathrm{CH}$ was made from their laboratory findings, signs and symptoms by clinical pediatric endocrinologists. Among these, cases of suspected dysgenetic $\mathrm{CH}$ were selected by excluding familial, iatrogenic (including excess or deficient iodine intake), transplacental autoimmune, goitrous and transient cases.

A total of 1,228,551 newborn babies (almost 100\% of live births in the general population) (the ratio of male to female babies $=1.058: 1)$ were screened and 429 patients with suspected dysgenetic $\mathrm{CH}$ (the ratio of male to female patients $=1: 1.201$ ) were found. The incidence of the patients was calculated as 3.5 cases/ $10^{4}$ tests $(1 / 2,850)$. The averaged incidence of the disorder in each month was calculated as follows. [averaged incidence of each month] $=$ [number of patients born in 3 months (in each month and one month pre- and post-the particular month)] / [number of newborn babies screened in the same 3 months].

Data of the prevalence of influenza were obtained from the Report on Survey of Infectious Diseases in Osaka.

\section{Statistical analysis}

The test for the proportion of the averaged incidence of the patients in each month throughout the tested period was performed by the Poisson distribution and by the $\chi^{2}$ test using the contingency table. The incidence of the patients in various seasons, its relation with the prevalence of influenza and that in sex differences were analyzed by the $\chi^{2}$ test.

\section{Results}

Fig. 1 shows the averaged incidence of dysgenetic $\mathrm{CH}$ in each month during the tested period. The occurrence was episodic, and the incidence was significantly higher in 14 months. The seasonal variation of the incidence of the patients is shown in Fig. 2. The incidence was significantly higher in the late autumn (from October to December).

\section{Discussion}

In the present study the incidence of occurrence of primary $\mathrm{CH}$ may be reliable since the study involved almost all newborn infants born in the Osaka area during the tested period by means of an identical mass-screening program. Most of the patients were assessed to be dysgenetic type since thyroid dysgenesis is known to be the most common cause of primary $\mathrm{CH}$, and diagnosis of suspected dysgenetic $\mathrm{CH}$ was made by experts of clinical pediatric endocrinologists who ruled out familial, iatrogenic, transplacental autoimmune, transient, and goitrous types of $\mathrm{CH}$.

The etiology of dysgenetic $\mathrm{CH}$ has been studied extensively and some candidate genes were reported [8-10] but it has not yet been clarified completely. The present study supports the hypothesis postulated by Miyai et al. that some environmental factors cause this disease $[3,4]$. It is well known that intrauterine infection of the fetus during early pregnancy induces some congenital anomalies of newborn babies [11-14]. The findings that congenital anomalies occurred epidemically after the prevalence of rubella in a restricted area supported a clinical entity of congenital rubella syndrome $[15,16]$. We made an analogical approach to examine the relationship between viral infection and occurrence of $\mathrm{CH}$. As an example, Table 1 shows that the incidence of dysgenetic $\mathrm{CH}$ in the period of 9 to 10 months after the prevalence of influenza is statistically higher than that in any other period. Although the correlation may be spurious this is suggestive data. Contradictory results have been reported concerning the relationship between maternal influenza and fetal anomalies [17-20]. A preliminary survey by Miyai et $a l$. [21,22] failed to obtain significant positive data of various antiviral antibodies including influenza in $\mathrm{CH}$. It is well known that some diseases are due to both the genetic background and environmental factors. For example, persons who had HLA-B27 often developed Reiter's syndrome after an episode of shigellosis [23]. Miyai et al. also reported that the incidence of the HLA-Aw24 antigen was significantly higher in mothers of Japanese patients of dysgenetic $\mathrm{CH}[24,25]$. 

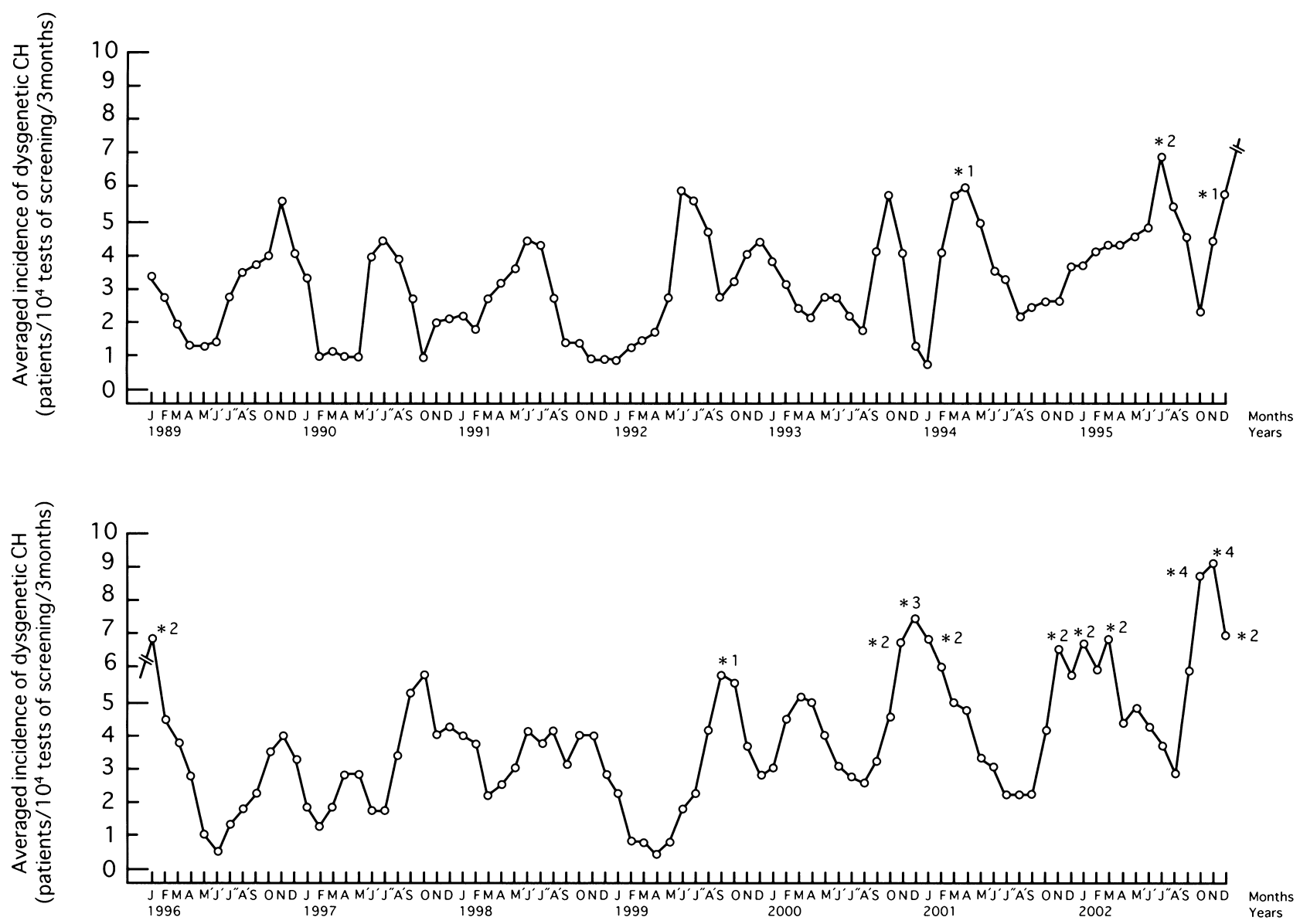

Fig. 1. Averaged incidence of dysgenetic $\mathrm{CH}$ in each month (see subjects and methods). J: January, F: February, M: March, A: April, M': May, J': June, J": July, A': August, S: September, O: October, N: November, D: December. *Statistically significant by the Poisson distribution(a), and by the $\chi^{2}$ test using the contingency table (b), *1: p<0.05 (a, b), *2: p<0.03 (a, b), *3: p<0.005 (a, b), *4: $\mathrm{p}<0.0005$ (a), $\mathrm{p}<0.001$ (b).

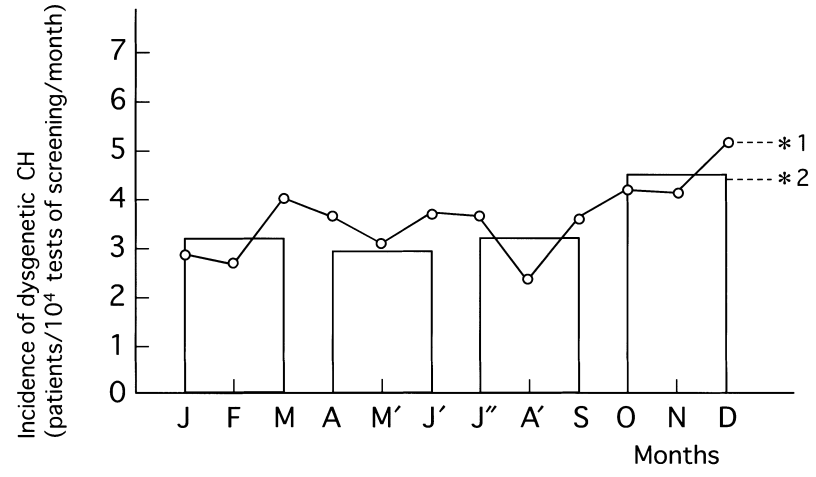

Fig. 2. Seasonal variation of incidence of dysgenetic $\mathrm{CH}$. Statistically significant by $\chi^{2}$ test, $* 1: \mathrm{p}<0.01, * 2$ : $\mathrm{p}<0.002$.

Furthermore, the present study revealed that the incidence of dysgenetic $\mathrm{CH}$ was significantly higher in female than in male babies $(p<0.02)$. These findings
Table 1. Relationship between the prevalence of influenza and incidence of dysgenetic $\mathrm{CH}$

\begin{tabular}{lrrr}
\hline & CH & no CH & \multicolumn{1}{c}{ total } \\
\hline prevalence of influenza & 181 & 413903 & 414084 \\
no prevalence of influenza & 248 & 814219 & 814467 \\
total & 429 & 1228122 & 1228551 \\
\hline
\end{tabular}

Statistically significant by $\chi^{2}$ test $(\mathrm{p}<0.0001)$

prevalence of influenza: period for 57 months which were 9 to 10 months after the prevalence of influenza (when more than 1,000 patients of influenza per month were found in the Osaka area), no prevalence of influenza: period for 111 months other than the above period, $\mathrm{CH}$ : number of patients with dysgenetic $\mathrm{CH}$, no $\mathrm{CH}$ : number of newborn babies without dysgenetic $\mathrm{CH}$ found by the mass-screening in the period

suggest some genetic factors for occurrence of $\mathrm{CH}$. Further studies are necessary to verify the hypothesis that an environmental factor such as viral infection in 
association with genetic background causes dysgenetic $\mathrm{CH}$.

\section{Acknowledgments}

The authors wish to thank Dr. T. Oura (past chairman) and past members of CONISO for their helpful suggestions and encouragement; Dr. M. Nakayama (director) and staffs of the Department of Clinical
Laboratory Medicine and Anatomic Pathology, Osaka Medical Center and Research Institute, and Mr. S. Matsumoto (manager) and staffs of the Clinical Laboratory, Osaka City Environment and Public Health Association for their task for neonatal screening for $\mathrm{CH}$; all clinical pediatric endocrinologists who reported valuable information of the final diagnosis of the patients with $\mathrm{CH}$; and staffs of the Department of Public Health and Welfare, Osaka Prefectural Government for their help.

\section{References}

1. Dussault JH (1991) Congenital hypothyroidism. In: Bravermann LE, Utiger RD (eds) Werner and Ingbar's The Thyroid. J. B. Lippincott Co. Philadelphia, New York, London, Hagerstown, $6^{\text {th }}$ Edition: $1222-1228$.

2. Childs B, Gardner LI (1954) Etiologic factors in sporadic cretinism. An analysis of ninety cases. Annals of Human Genetics 19: 90-96.

3. Miyai K, Ichihara K, Amino N, Nose O, Yabuuchi H, Tsuruhara T, Oura T, Kurimura T (1979) Seasonality of birth in sporadic cretinism. Early Hum Dev 3: 8588.

4. Miyai K, Connelly JF, Folley TP Jr, Irie M, Illig R, Lie SO, Morissette J, Nakajima H, Rochiccioli P, Walfish PG (1984) An analysis of variation of incidence of congenital dysgenetic hypothyroidism in various countries. Endocrinol Japon 31: 77-81.

5. Miyai K, Ishibashi K, Kumahara Y (1976) Enzymelinked immunoassay of thyrotropin. Clin Chim Acta 67: 263-268.

6. Kato N, Ishii S, Naruse H, Irie M, Arakawa H, Tsuji A (1980) Enzyme immunoassay of thyroid-stimulating hormone using dried blood samples. A simple technique of screening for congenital hypothyroidism. Analyt Lett 13: 1555-1565.

7. Miyai K, Ishibashi K, Kawashima M (1981) Two-site immunoenzymometric assay for thyrotropin in dried blood samples on filter paper. Clin Chem 27: 14211423.

8. Macchia PE, Lapi P, Krude H, Pirro MT, Missero C, Chiovato L, Souabni A, Baserga M, Tassi V, Pinchera A, Fenzi G, Grüters A, Busslinger M, DiLauro R (1989) PAX8 mutations associated with congenital hypothyroidism caused by thyroid dysgenesis. Nat Genet 19: 83-86.

9. Clifton-Bligh RJ, Wentworth JM, Heinz P, Crisp MS, John R, Lazarus JH, Ludgate M, Chatterjee VK (1998) Mutation of the gene encoding human TTF-2 associated with thyroid agenesis, cleft palate and choanal atresia. Nat Genet 19: 399-401.
10. Nogeira CR, Nguyen LQ, Coelho-Neto JR, Arseven OK, Jameson JL, Kopp P, Mederios-Neto GA (1999) Structural analysis of the thyrotropin receptor in four patients with congenital hypothyroidism due to thyroid hypoplasia. Thyroid 9: 523-529.

11. Henshaw JB (1966) Cytomegalovirus complementfixing antibody in microcephaly. $N$ Engl J Med 275: 476-479.

12. South MA, Tompkins WA, Morris CR, Rawls WE (1969) Congenital malformation of the central nervous system associated with genital type (type 2 ) herpes virus. J Pediatr 75: 13-18.

13. Williamson AP (1975) The varicella-zoster virus in the etiology of severe congenital defects. A survey of eleven reported instances. Clin Pediatr 14: 553-555, 558559.

14. Lundstrom (1962) Rubella during pregnancy. A followup study of children born after an epidemic of rubella in Sweden, 1951, with additional investigations on prophylaxis and treatment of maternal rubella. Acta Paediatr (Suppl 133): 1-110.

15. Sever JL, Hardy JB, Nelson KB, Gilkeson MR (1969) Rubella in the collaborative perinatal research study. II. Clinical and laboratory findings in children through 3 years of age. Am J Dis Child 118: 123-132.

16. Ueda K, Nishida Y, Oshima K, Yoshikawa H, Nonaka S (1978) An explanation for the high incidence of congenital rubella syndrome in Ryukyu. Am J Epidemiol 107: 344-351.

17. Coffey VP, Jessop WJ (1959) Maternal influenza and congenital deformities: a prospective study. Lancet 2 : 935-938.

18. Hardy JM, Azarowicz EN, Mannini A, Medearis DN Jr, Cooke RE (1961) The effect of Asian influenza on the outcome of pregnancy, Baltimore, 1957-1958. Am $J$ Public Health 51: 1182-1188.

19. Walker WM, McKee AP (1959) Asian influenza in pregnancy; relationship to fetal anomalies. Obstet Gynecol 13: 394-398. 
20. Wilson MG, Stein AM (1969) Teratogenic effects of Asian influenza. An extended study. JAMA 210: 336337.

21. Miyai K, Kurimura T, Nose O, Turuhara T (1981) Rubella antibody in neonatal hypothyroidism due to thyroid dysgenesis. Early Hum Dev 5: 215-216.

22. Miyai K, Hata N, Kurimura T, Nose O, Harada T, Tsuruhara T, Kusuda S, Satake R, Mizuta H, Amino N, Ichihara K (1986) Anti-viral antibodies in congenital hypothyroidism. In: Mederios-Neto G, Gaitan E (eds) Frontiers in Thyroidology, Plenum Publishing Co., New York, vol 2: 1225-1229.
23. Calin A, Fries JF (1976) An "experimental" epidemic of Reiter's syndrome revisited. Follow up evidence on genetic and environmental factors. Ann Intern Med 84: 564-566.

24. Miyai K, Mizuta H, Nose O, Fukunishi T, Hirai T, Matsuda S, Tsuruhara T (1980) Increased frequency of HLA-Aw24 in congenital hypothyroidism in Japan. $N$ Engl J Med 303: 226.

25. Miyai K, Fukunishi T, Mizuta H, Amino N, Nose O, Tsuruhara T (1984) HLA-A and -B antigens in Japanese patients with congenital hypothyroidism and their parents. Tissue Antigens 23: 210-216. 